Journal of Contemporary Eastern Asia, Volume 10, No.2: 35-40

http://dx.doi.org/10.17477/jcea.2011.10.2.035

\title{
Coping with Violence in the Thai-Cambodian Border: The Silence of the Border
}

\author{
Otto F. von Feigenblatt*
}

The recent listing of Preah Vihear Temple as a World Heritage Site has awakened a longtime simmering border dispute between Thailand and Cambodia over a few square kilometers surrounding the ancient Khmer Temple. While the listing of the site by UNESCO was expected to revive the economy of the impoverished border towns near the temple due to the increased tourism and funding for the preservation of the archeological site, it has had the opposite effect due to the sharp increase in violent conflict carried out by the armed forces and nationalist activists from both sides. Military skirmishes and violent protests have brought the local economy to a halt in addition to causing considerable physical damage to the local infrastructure and to the local transnational network of ethnic Kui, local business owners, Khmer and Thai villagers. This paper shows how the dispute is viewed and undertaken by three distinct communities involved in the conflict, the militaries, the metropolitan political elites and activists, and the local villagers. The three communities represent three different cultures of conflict with different interests and most importantly with differential access to the media and official representations of the dispute.

\section{Introduction}

Thailand and Cambodia have a history of disputes since the time of the Khmer Empire in the $11^{\text {th }}$ century (Heidhues, 2000; Kershaw, 2001; Wyatt, 2003). The border has moved countless times with the Khmer Empire exercising considerable control over the predecessor statelets of Thailand and then losing territory to Siam starting in the $15^{\text {th }}$ century

\footnotetext{
* Otto F. von Feigenblatt is an elected Fellow of the Royal Asiatic Society of Great Britain and Ireland, an Academician of the Constantinian Academy of Arts, Letters, and Sciences (Palermo, Italy) and a member of the United States committee of the Council for Security and Cooperation in the Asia Pacific (CSCAP). He is an Adjunct Professor of Political Science at Millenia Atlantic University (Doral, Florida). Otto F. von Feigenblatt is the author of Human Security in the Asia Pacific Region: Security Challenges, Regional Integration, and Representative Case Studies, YKING Books, Jaipur, India, 2010. His research has appeared in more than ten peer reviewed academic journals and he is a member of the editorial boards of the Journal of Contemporary Literature and Entelequia. Otto F. von Feigenblatt is serving as the editor in chief of the Journal of Alternative Perspectives in the Social Sciences and as one of the chief editors of the Journal of Postcolonial Cultures and Societies.
} 
(Kershaw, 2001; Singh, 1962). Cambodia's transition into a French Protectorate in the $19^{\text {th }}$ century further complicated the relationship between the two Southeast Asian countries by introducing a third party (John, 1994). French power helped Cambodia regain considerable territory including two entire provinces (Cuasay, 1998). France also conducted the first modern mapping of the border area which resulted in the demarcation of the present border (Cuasay, 1998; Gallis, 2009). While a brief Thai invasion during World War II returned the two provinces to Japanese control, the Treaty of Washington at the end of the War forced Thailand to return the territory and reinstated the treaties signed with France before the War (Singh, 1962).

During the 1950s and early 1960s, Thailand exercised control over the Temple and stationed a few troops in the vicinity (John, 1994). The Thai flag was raised on top of the Temple and permits were issued to local villagers to conduct different activities by Thai authorities (Cuasay, 1998). Nevertheless, Thailand used maps showing the temple on the Cambodian side of the border during most of the early $20^{\text {th }}$ century which seemed to prove that Thailand accepted Cambodia's ultimate sovereignty over the area (Chan, 2004; Cuasay, 1998). Cambodia started to assert its sovereign claims over the area in the early 1960s which led to some armed clashes between the two sides and in 1962 the World Court of Justice (ICJ) ruled in favor of Cambodia regarding ownership of the temple (Chan, 2004; Cuasay, 1998; Gallis, 2009; Hinton, 2006; John, 1994). At this point Thailand strongly protested by ultimately removing the flag in standing position and handed over control over the temple (Singh, 1962). It should be noted that ownership over the surrounding territory was not decided by the court which has led to considerable problems in terms of violent incidents in the border ("Asia: ASEAN and the temple of doom; South-East Asia," 2008).

The decision of UNESCO in 2008 to list the temple as a protected World Heritage Site reignited the disputed and led to continued fighting along the border (Gallis, 2009). Both countries increased their troop levels on their sides of the border and the fighting resulted in considerable deaths and property damage ("Asia: ASEAN and the temple of doom; South-East Asia," 2008; "Asia: Whose Angkor Wat?; Cambodia v Thailand," 2003). Probably the greatest casualty of the violence was tourism and the area's economy. Nevertheless it should be noted that nationalist groups on both sides of the border benefited from the fighting as evidenced by elections in Cambodia and the removal of moderate politicians in Thailand and their replacement by ultranationalist ones (von Feigenblatt, 2009, 2010b; Nanuam, 2011; Thayer, 2009).

The following sections discuss how three important interest groups view and pursue the dispute over the land surrounding the temple in order to show how the perspectives that have received the least attention are those of the people who actually live along the border and who suffer most of the consequences of the fighting. Moreover, ritualized and symbolic aspects of the fighting are discussed in order to elucidate the reasons behind the fighting over an apparently unimportant area with few natural resources.

\section{Theoretical Framework}

This brief exploratory essay borrows the important concept of "violent imaginaries" from Ingo W. Schröder and Bettina E. Schmidt (Schröder \& Schmidt, 2001). Their emphasis on the role that a society's culture plays in terms of the way political elites attempt to legitimize violence is particularly useful in attempting to understand the present dispute which 
involves little tangible resources while being trumpeted as of considerable importance by elites on both sides of the border (Schröder \& Schmidt, 2001, p. 4). The role of past narratives about great battles waged between the two sides becomes part of "violent imaginaries" which are then used to legitimize the present violence and thus make the present dispute part of a much broader historical struggle for national survival and honor (Schröder \& Schmidt, 2001, p. 10). Another aspect of the concept of "violent imaginaries" that is useful for this brief study is the importance of having an audience for the violence. In other words, violence becomes symbolic action carrying an important message regarding legitimacy (Schröder \& Schmidt, 2001, p. 8).

Bowman's analysis of the role of boundaries in terms of identity and violence is also applicable to this case study. His review of the literature regarding the role of identity in violence shows that the crystallization of borders during state formation leads to violence based on the dynamic of separating the world between "us" and the "other" (Bowman, 2001). While Bowman's emphasis on identity formation and "othering" is useful, it is important to keep in mind Schröder and Schmidt's assertion that "the decision to go to war is made by those who hold power" and that in order for them to choose this course of action, they would expect to be better off in terms of material interests (Schröder \& Schmidt, 2001, p. 4). Thus this exploratory essay follows the tradition of critical studies in terms of attempting to expose hidden structures of socio-political and economic domination (Stuart Sim, 2005).

\section{Three Communities and Three Perspectives}

It is important to understand how the dispute over the Preah Vihear temple has been framed by the different communities that have been historically involved in the conflict. Firstly, the political elites and supporting middle classes on both sides of the border tend to rely on two recurrent frames of reference. Nationalism based on narratives of a pre-determined/predestined historical development towards the present nation-states is the most common frame of reference for this community on both sides of the border (von Feigenblatt, 2010d; Hinton, 2006; Thayer, 2009). Bowman's explanation of the role of identity formation in fomenting violence is pertinent here (Bowman, 2001). Both sides stress the difference between those inside the nation-state and those outside of it. Thus the process of "othering" is used to dehumanize the other side, to reduce trust for the intentions of the other, and ultimately to justify the use of force and diplomatic coercion (Bowman, 2001). Evidence of this is found in the aggressive and insulting rhetoric used by politicians on both sides as well as by the middle class nationalist groups that support them (Hinton, 2006). This frame of reference is intimately tied to arguments dealing with principles of international law. This discipline reifies the nation-state as the sole independent agent operating in the international system of sovereign states (August, 1995; von Feigenblatt, 2010c; Jackson \& Nexon, 2009). The result of this approach is that the needs and interest of the nation-states become the sole criteria for pursuing the dispute. Needless to say, those who have the power to define "national interest" expect to benefit from the violent pursuit of the dispute (Schröder \& Schmidt, 2001). Political changes in both Bangkok and Phnom Penh show that both the Cambodian People's Party (CPP) and the Democrat Party of Thailand stand to benefit from propping up their nationalist credentials and diverting attention from domestic problems in order to contest elections and appease opposition movements ("Asia: ASEAN 
and the temple of doom; South-East Asia," 2008; von Feigenblatt, Suttichujit, Shuib, Keling, \& Ajis, 2010; "PAD vow to reclaim Thai soil at miniature Preah Vihear," 2009; Thayer, 2009).

The military and security communities on both side of the border follow a similar logic to that of politicians and middle class nationalists. Internal security and finding a way to justify continued funding after the passing of the communist threat figure prominently as motivations to pursue this dispute violently (von Feigenblatt, 2010a, 2010b; Ungpakorn, 2007, 2010). Thus, the security community becomes the incarnation of the violent impulses of the nation-state and is charged with upholding national dignity and honor by physically punishing the "other". This community makes use of similar historical narratives to those used by the first community but with added mysticism and conviction (Nanuam, 2011). The goal becomes to protect sovereign territory at all costs because each inch embodies the honor, dignity, history, and survival of the entire nation-state (Bowman, 2001).

It should be clear by now that neither one of the first two communities take into consideration the needs or interests of people who actually live along the disputed border. The level of analysis for the first two communities is at the macro nation-state level and decisions are based on the perceived national interest of the capital in the name of the abstraction called "nation". What about the villages that exist and have existed along the border for hundreds of years? What about the Thais and Cambodians who used to cross the border on a daily basis to do business on the other side of the border? What about the businesses along the border that depend on tourism? Finally, what about the Kui people living on both sides of the border?

\section{The Silence of the Border}

While there are countless studies and journalistic reports dealing with the activities of the militaries, the decisions of the political leaders, and esoteric maps demarcating the border, there are few journalistic reports that even mention the wellbeing and experiences of those who live and do business along the border (Chan, 2004; Cuasay, 1998; Thayer, 2009). The few reports about local villagers and business owners simply mention that they have been negatively affected economically by the unrest and that there have been several violent clashes with nationalist activists protesting along the border ("Asia: ASEAN and the temple of doom; South-East Asia," 2008). Moreover, there is no mention of the fact that a large proportion of the people living along both sides of the border is part of a distinct ethnic group called Kui which has its own history and language (Cuasay, 1998). Thai reports are also silent on the fact that more than fifty percent of the inhabitants of the district speak northern Khmer as their first language rather than Thai (Nanuam, 2011).

Borders in Southeast Asia are porous and diffuse, and rather than simple delimitations on a map they represent liminal spaces reflecting the region's past and future more than its political present (Tagliacozzo, 2001; Vaughan-Williams, 2008). The territory surrounding Preah Vihear is no exception and is characterized by its multiethnic and multilingual population and syncretic culture and history (Mulder, 1996). A critical hypothesis explaining the deafening silence of the border, understood as a liminal space with a particular population and cultural mix, is that the reality on the ground does not fit the essentialist narratives of the first two "communities" discussed in this paper. There is no historical feud between clearly defined ethnic groups taking place along the border but rather a well inte- 
grated and interdependent liminal community trying to make sense of a dispute not of their own making and that actively ignores their needs and interests while denying their own existence. Evidence to the previous assertion is the high degree of intermarriage between ethnic groups, the multiethnic makeup of the villages, and the ubiquity of spoken Kui and norther Khmer even on the Thai side of the border (Cuasay, 1998; Heidhues, 2000; Mulder, 1996). The few requests made by local business owners and villages have been to reopen the border in order to continue with their daily activities, which unsurprisingly involve people and places on both sides of the border ("Asia: ASEAN and the temple of doom; South-East Asia," 2008). While there are no studies on the perceptions and activities of the transnational population living along the disputed territory, it is clear that their needs and interests are not the same as those of the political elites, security forces, and middle classes of the capitals.

A study similar to the one undertaken by Nordstrom in Mozambique is needed in this case (Nordstrom, 1997). While the situation on the ground is not nearly as violent and dangerous as it was in Mozambique while Nordstrom was conducting her research, the lives of those living near the disputed territory have been disrupted by the escalation of hostilities between the two armed forces and their nationalist hooligans from the capitals. It is important to understand the way those most directly affected by the dispute experience the violence in order to break the discursive monopoly over conflict narratives controlled by political and security elites. The territory around Preah Vihear is more than just a dark line on a map it is the home of hundreds of people whose existence and reality is one of cultural syncretism, multilingualism, mobility, and interdependence.

\section{References}

Asia: ASEAN and the temple of doom; South-East Asia. (2008). The Economist, 388(8590).

Asia: Whose Angkor Wat?; Cambodia v Thailand. (2003). The Economist, 366(8309), 57.

August, R. (1995). Public International Law: Text, Cases, and Readings (Paperback ed.). New Jersey: Prentice Hall.

Bowman, G. (2001). The violence in identity. In B. E. Schmidt \& I. W. Schröder (Eds.), Anthropology of Violence and Conflict (pp. 25-46). New York: Routledge.

Chan, P. C. W. (2004). Acquiescense/Estoppel in International Boundaries: Temple of Preah Vihear Revisited. Chinese Journal of International Law, 3(2), 421-439.

Cuasay, P. (1998). Borders on the Fantastic: Mimesis, Violence, and Landscape at the Temple of Preah Vihear. Modern Asian Studies, 32(4), 849-890.

von Feigenblatt, Otto F. (2009). The Thai Ethnocracy Unravels: A Critical Cultural Analysis of Thailand's Socio-Political Unrest. Journal of Alternative Perspectives in the Social Sciences, 1(3), 583-611.

von Feigenblatt, Otto F. (2010a). Human Security in the Asia Pacific Region: Security Challenges, Regional Integration, and Representative Case Studies (Hardcover ed.). Jaipur: YKING BOOKS.

von Feigenblatt, Otto F. (2010b). The Human Security Theory of Integrative Negotiation for Sociopolitical Conflicts: The Thai Color Divide as a Case Study Asia Pacific World, 1(2), 61-82.

von Feigenblatt, Otto F. (2010c). International Policymaking: The Case of the Norm of the Responsibility to Protect. Entelequia: Revista Interdisciplinar, Spring 2010(11), 267-272.

von Feigenblatt, Otto F. (2010d, April 09, 2010). Thailand's Struggle over Legitimacy. UPI Asia.com, pp. 1-3. Retrieved April 9, 2010, from http://www.upiasia.com/Politics/2010/04/09/thailands_struggle_over_legitimacy/2024/ 
von Feigenblatt, Otto F., Suttichujit, V., Shuib, M. S., Keling, M. F., \& Ajis, M. N. e. (2010). Weapons of Mass Assimilation: A Critical Analysis of the Use of Education in Thailand. Journal of Asia Pacific Studies, 1(2), 292-311.

Gallis, A. (2009). Symposium: International Commercial Arbitration: Fifty Years after New York Convention: UNESCO Documents and Procedure: The Need to Account for Political Conflict When Designating World Heritage Sites. Georgia Journal of International and Comparative Law, 38(Spring), 127.

Heidhues, M. S. (2000). Southeast Asia: A Concise History. London: Thames \& Hudson.

Hinton, A. (2006). Khmerness and the Thai 'Other': Violence, Discourse and Symbolism in the 2003 AntiThai Riots in Cambodia. Journal of Southeast Asian Studies, 37(3), 445-469.

Jackson, P. T., \& Nexon, D. H. (2009). Paradigmatic Faults in International Relations Theory. International Studies Quarterly, 53(4), 907-930.

John, R. B. S. (1994). Preah Vihear and the Cambodia-Thailand Borderland. IBRU Boundary and Security Bulletin(January ), 64-68.

Kershaw, R. (2001). Monarchy in South-East Asia: The Faces of Tradition in Transition (First ed.). London: Routledge.

Mulder, N. (1996). Inside Southeast Asia: Religion, Everyday Life, and Cultural Change. Chiang Mai: Silkworm Books.

Nanuam, W. (2011). Keep your talismans close, boys: Army says troops need protection against Khmer black magic. [Electronic Version]. Bangkok Post. Retrieved February 12, 2011, from http://www.bangkokpost.com/lite/topstories/221185/keep-your-talismans-close-boys

Nordstrom, C. (1997). A Different Kind of War Story. Philadelphia: University of Pennsylvania Press.

PAD vow to reclaim Thai soil at miniature Preah Vihear [Electronic. (2009). Version]. Prachatai. Retrieved October 12, from http://www.prachatai.com/english/node/1422

Schröder, I. W., \& Schmidt, B. E. (2001). Introduction: Violent Imaginaries and Violent Practices. In I. W. Schröder \& B. E. Schmidt (Eds.), Athropology of Violence and Conflict (pp. 1-24). New York: Routledge.

Singh, L. P. (1962). The Thai-Cambodian Temple Dispute. Asian Affairs, 2(8), 23-26.

Stuart Sim, B. V. L. (2005). Introducing Critical Theory. London: Icon Books.

Tagliacozzo, E. (2001). Border Permeability and the State in Southeast Asia: Contraband and Regional Security. Contemporary Southeast Asia, 23(2), 254-275.

Thayer, C. A. (2009). Cambodia: The Cambodian People's Party Consolidates Power. Southeast Asian Affairs, 2009, 85-101.

Ungpakorn, G. J. (2007). A Coup for the Rich: Thailand's Political Crisis. Bangkok: Workers Democracy Publishing.

Ungpakorn, G. J. (2010). Thailand's Crisis \& the Fight for Democracy. London: WDPress.

Vaughan-Williams, N. (2008). Borders, Territory, Law. International Political Sociology, 2(4), 322-338.

Wyatt, D. K. (2003). Thailand: A Short History (Thailand ed.). Chiang Mai: Silkworm Books. 